\title{
アンタゴニストによるTLR7の阻害機構の構造基盤
}

東京大学大学院薬学系研究科 張 志寛

\section{Zhikuan ZHANG: Structural Basis for the Inhibition Mechanism of TLR7}

自然免疫システムは原始的な生物を始め, 高等生物ま で備われる生体防御機構である. ${ }^{1)}$ Toll様受容体 (Toll-like receptor, TLR）は多くの脊椎動物に存在する自然免疫受容 体の一種類であり, 自然免疫システムの第一線で重要な役 割を果たしている. ${ }^{2)}$ ヒトではTLR1〜TLR10の十種類のTLR が同定されており，それぞれが異なる病原体分子パターン を認識する.3)すべてのTLRは1型膜タンパク質であり, 細 胞外ロイシンリッチリピート (LRR) ドメイン, 一回膜貫通 ドメインおよび細胞内トール／インターロイキン -1 受容体 (TIR) ドメインにより構成されている.一般的に, TLRはリ ガンド非存在下では単量体として存在しており, LRRドメ インがリガンドを認識することによって, TLRの活性化型 二量体の形成が誘導され, 免疫反応が引き起こされる.3)

Toll-like receptor 7 (TLR7) は, ヒト免疫不全ウイルスな どの RNAウイルスを認識する受容体である. ${ }^{4}$ 現在世界的 に流行しているSARSコロナウイルス 2 に活性化される と知られている. ${ }^{5)}$ TLR7は, 一本鎖 RNA, グアノシンおよ び特定の合成低分子リガンドによって活性化される，筆 者らはこれまでに, アゴニストによるTLR7の活性化機構 を一連のTLR7/リガンド複合体の結晶構造を通じて解明 した. ${ }^{6,7)}$ TLR7 は2つのリガンド結合部位を有し, サイト 1 はグアノシンおよび合成低分子リガンドを認識し，直接的 にTLR7の二量体化を誘導する。 アロステリック結合部位 のサイト 2 はウリジン塩基を含む短鎖一本鎖 RNA を認識 し, TLR7のサイト1に結合するリガンドに対する結合親 和性を増加させる. TLR7はウイルスの感染を排除するた めの重要な受容体であるが, ウイルスによる TLR7の過剰 な活性化は感染症の重症化の起因になる場合もある。ま た, 通常ではTLR7はエンドリソソームに局在しているた め, 内因性の RNA 分子との接触が遮断されている.8) しか し, 内在性のRNAによるTLR7の好ましくない活性化は 特定の自己免疫疾患の病因となっている.よって, TLR7 をターゲットするアンタゴニストはTLR7の過剰な活性化 に起因する疾患の治療薬として開発されている.9)

筆者らの共同研究者はTLR7のアゴニスト (Cpd-3)を 誘導体化することで, 2 種類の TLR7 特異的なアンタゴ ニストを開発していた (図1a). ${ }^{10)}$ 本研究では, これらの アンタゴニストによるTLR7の阻害機構を原子レベルで 日本結晶学会誌 第 63 巻 第3 号 (2021)
可視化するため, X 線結晶構造解析とクライオ電子顕微 鏡解析を併用して, TLR7/アンタゴニスト複合体の立体 構造および阻害機構を明らかにした.10)

構造解析に適した高純度のTLR7 タンパク質を調製す るため, プロテイン A タグをつけたサル TLR7の LRR ドメ インを安定に発現するショウジョウバエ $\mathrm{S} 2$ 細胞を大量培 養し, 分泌されたTLR7タンパク質を精製した。さらに, TLR7のZ-loop領域（TLR7ファミリーで保存された自己 阻害構造モチーフ）を酵素切断し, 自己阻害が解除され たTLR7タンパク質を調製した. 本研究の初期段階では, アゴニストのCpd-3 およびアンタゴニストの Cpd-6 と Cpd-7 を添加しながら（図1a）, TLR7の結晶化実験を実施した。 さまざまな結晶化条件の最適化および複数の結晶のX線 回折実験を行った結果, TLR7/Cpd-3 複合体およびTLR7/ Cpd-6複合体の結晶構造を決定したが, TLR7/Cpd-7複合 体に関しては良質の結晶が得られず, 構造決定に至らな かった. TLR7/Cpd-3 複合体の結晶構造は活性型二量体 構造を形成しており, Cpd-3 はアゴニストとして TLR7の

(a)

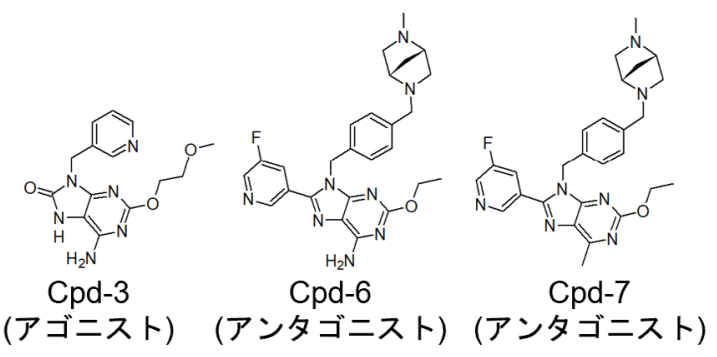

(b)
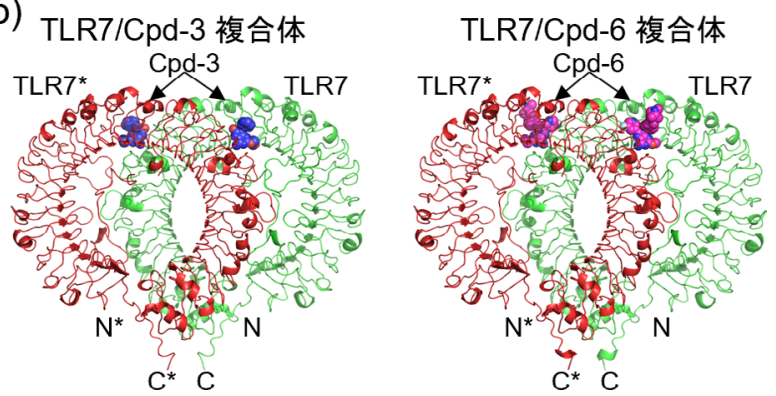

図1 TLR7のリガンドと TLR7の結晶構造. (Ligands of TLR7 and the crystal structures of TLR7.) (a) TLR7のアゴニ ストおよびアンタゴニストの化学構造式. (b) TLR7/ Cpd-3 およびTLR7/Cpd-6複合体の結晶構造. 
サイト1に結合していた（図1b)。これは既報のTLR7/ア ゴニスト複合体構造とよく一致している. 驚くべきこと に，Cpd-6がアンタゴニストであるにもかかわらず，TLR7/ Cpd-6 複合体の結晶構造はCpd-6がサイト 1 に結合し活 性型二量体構造を形成していた（図1b)。また, Cpd-6の 結合様式も Cpd-3 の結合様式と類似している. そのため, TLR7/Cpd-6複合体の結晶構造情報だけではCpd-6による TLR7の阻害機構を解釈することは困難である。

単一の結晶構造は静的なものであり, アンタゴニスト によりTLR7二量体構造のゆらぎが誘導される可能性が 考えられる. そこで, アンタゴニスト存在下でのTLR7の 構造ダイナミクスを可視化するため, クライオ電顕単粒 子解析に移行した。 より安定な複合体を得るため, グル タルアルデヒドで架橋されたTLR7/Cpd-3, TLR7/Cpd-6, TLR7/Cpd-7複合体を調製し, クライオ電顕で観察した. 興味深いことに, これら三種類の複合体はそれぞれ異な るコンフォメーションを形成していた(図2). TLR7/Cpd-3 複合体の電顕マップはクローズ型構造をとっており, 活 性型二量体である結晶構造と一致していた. TLR7/Cpd-6 複合体は, 結晶構造で示したクローズ型構造と, 本研究 で初めて解明されたオープン型構造の両方が観察された。 TLR7/Cpd-7複合体は, 主にオープン型構造を形成してい た.オープン型構造における2つの TLR7プロトマーのC 末端は, クローズ型構造と比べて互いに離れている。 その ため, オープン型構造は, シグナル伝達に不可欠な細胞内 TIR ドメインの接近を妨げることになり，TLR7の活性化 を阻害するという，不活性型二量体構造と言える. Cpd-3, Cpd-7はそれぞれ1つの構造を誘導するが, Cpd-6は, TLR7 の構造ダイナミクスを誘導することで, 安定したTLR7活 性型二量体構造が形成できなくなることにより, 結果的 にTLR7の活性化を阻害することを明らかにした。

図2で示した電顕マップは粒子の向きの偏りが原因 で, 全体的なコンフォメーションは同定できたが, 詳細 構造を可視化することはできなかった。この問題はクラ イオ電顕単粒子解析ではしばしば遭遇する。 そこで, 粒 子の向きの偏りを改善するため, 部分的にプロテイン A タグの非切断の TLR7 タンパク質 (ゲルろ過クロマトグ ラフィー精製時にプロテイン A夕グの切残りを〜 $50 \%$ 含んだ画分）を電顕解析に用いた，その結果，粒子の向 きのバリエーションが増え, TLR7/Cpd-7複合体のオー プン型構造を2.8 ^分解能で解明できた(図3). TLR7の 二量体化界面の内側に, 新規アンタゴニスト結合部位が 観察された（図3）。興味深いことに, このアンタゴニス 卜結合部位は, アゴニストと比べて, アンタゴニストの 結合様式が大きく変化しているものの, クローズ型構造 のサイト 1 と空間的に近い. Cpd-7 はTLR7 プロトマーの 両方と相互作用し, 疎水性相互作用と水素結合を介し て認識されていた。

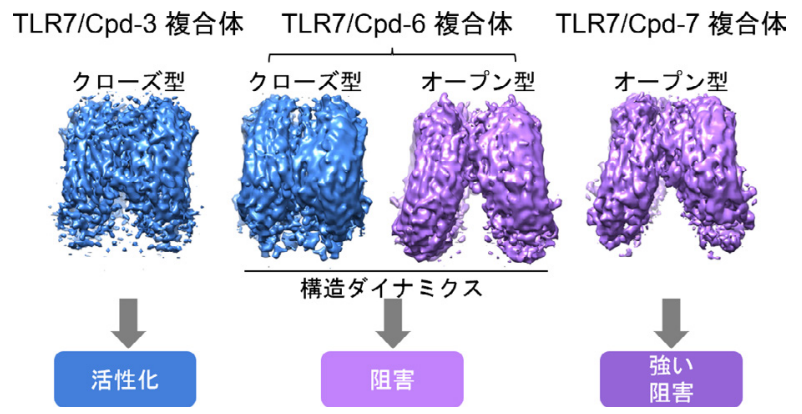

図2 三種類のTLR7/リガンド複合体のクライオ電顕 マップの側面図. (Cryo-EM reconstructions of three different TLR7/ligand complexes.)
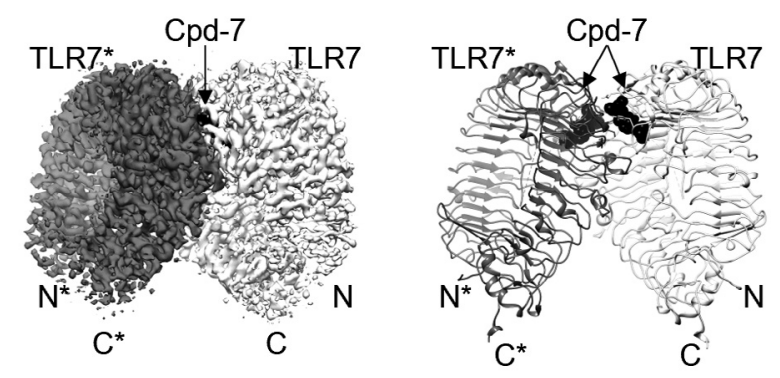

図3 TLR7/Cpd-7複合体のクライオ電顕構造. (Cryo-EM structure of TLR7/Cpd-7 complex.) 左の図 : TLR7/Cpd-7 複合体のクライオ電顕マップ (2.8 ^分解能). 右 の図：TLR7/Cpd-7 複合体のクライオ電顕構造.

TLR7/アンタゴニスト複合体の結晶構造およびクライ 才電顕構造に基づいて, アンタゴニストによるTLR7の 阻害機構を解明した：Cpd-6 抢よびCpd-7は, TLR7 の構 造ダイナミクスまたはTLR7のオーブン型構造を誘導し, 安定したTLR7 活性化二量体の形成を阻害する。本研究 で得られた構造的知見は, TLR7をターゲットするアン タゴニストの設計の構造基盤となる.

\section{謝 辞}

本研究は大日本住友製薬株式会社, 横浜市立大学, 理化学研究所, 高エネルギー加速器研究機構および東京 大学医科学研究所, 東京大学大学院医学系研究科との 共同研究です. 記してここに感謝申し上げます.

\section{文 献}

1) C. A. Janeway Jr, et al:: Annu. Rev. Immunol. 20, 197 (2002).

2) O. Takeuchi and S. Akira: Cell 140, 805 (2010).

3) L. A. O'neill, et al.: Nat. Rev. Immunol. 13, 453 (2013).

4) F. Heil, et al.: Science 303, 1526 (2004).

5) M. A. Moreno-Eutimio, et al.: Microbes Infect. 22, 226 (2020).

6) Z. Zhang, et al.: Immunity 45, 737 (2016).

7) Z. Zhang, et al:: Cell Rep. 25, 3371 (2018).

8) O. Majer, et al.: Curr. Opin. Immunol. 44, 26 (2017).

9) R. Patra, et al.: J Med. Virol. 94, 615 (2020).

10) S. Tojo, et al.: Nat. Commun. 11, 1 (2020). 


\section{応力に対し変形する分子結晶：明確な結晶構造変化が鍵}

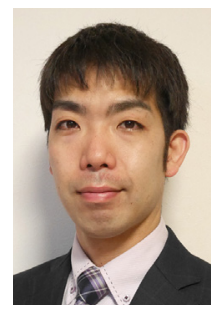

関 朋宏 Tomohiro SEKI

静岡大学 理学部 化学科

Department of Chemistry, Faculty of Science, Shizuoka University

T 422-8529 静岡市駿河区大谷 836 理学部B313

836 Ohya, Suruga-ku, Shizuoka 422-8529, Japan

e-mail: seki.tomohiro@shizuoka.ac.jp

最終学歴: 千葉大学大学院

専門分野: 有機化学, 機能性材料化学

現在の研究テーマ: 刺激応答性発光材料の研究

\section{化学置換なしで高い伝導度を示すプロトン伝導体}

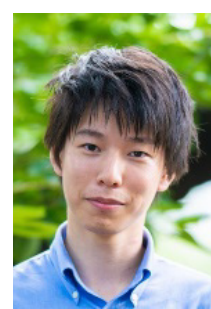

\section{村上泰斗 Taito MURAKAMI}

東北大学工学研究科

Department of Electronic Engineering, Tohoku University

干 980-8579 宮城県仙台市青葉区荒巻字青葉 6-6-05 6-6-05 Aza-Aoba, Aramaki, Aoba-ku, Sendai, Miyagi 980-8579, Japan

e-mail: taito.murakami.b7@tohoku.ac.jp 最終学歴：京都大学大学院工学研究科博士課程 修了

専門分野：無機固体化学, 磁性材料

現在の研究テーマ：高周波領域での使用に資す る磁性材料の開発

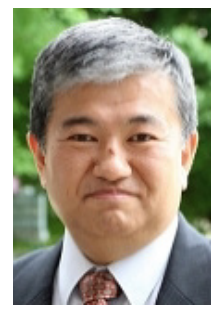

八島正知 Masatomo YASHIMA

東京工業大学理学院化学系

School of Chemistry, Tokyo Institute of Technology

干 152-8551 東京都目黒区大岡山2-12-1 西 4 号館 410 号室

W4-410, 2-12-1 Ookayama, Meguro-ku, Tokyo 1528551, Japan

e-mail: yashima@cms.titech.ac.jp 最終学歴：東京工業大学大学院博士課程修了 専門分野：無機固体化学

現在の研究テーマ：イオン伝導体等新構造型機 能性材料の探索, 結晶構造解析と構造物性

\section{水 XIXの発見一複数通りの配向秩序化}

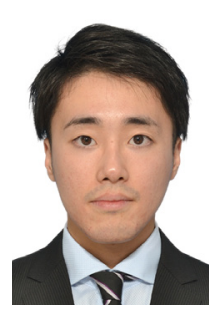

山根 崚 Ryo YAMANE

東北大学 金属材料研究所

Institute for Materials Research Tohoku University

干 980-8577 宮城県仙台市青葉区片平 2-1-1

2-1-1 Katahira, Aoba-ku, Sendai, 980-8577 Japan

e-mail: ryo.yamane.c2@tohoku.ac.jp

最終学歴: 東京大学大学院理学研究科博士課程 修了

専門分野：固体化学物理 高圧力科学

現在の研究テーマ: 含水固体の構造・物性 趣味：自然に触れること（山登りなど）

\section{アンタゴニストによるTLR7 の阻害機構の構造基盤}

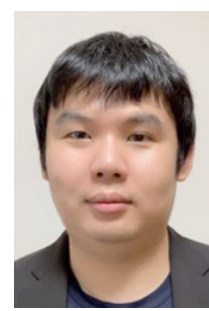

張 志寞 Zhikuan ZHANG

東京大学大学院薬学系研究科

Graduate School of Pharmaceutical Sciences, the University of Tokyo

干 113-0033 東京都文京区本郷 7-3-1

7-3-1 Hongo, Bunkyo-ku, Tokyo 113-0033, Japan

e-mail: zhang@mol.f.u-tokyo.ac.jp

専門分野: 構造生物学

現在の研究テーマ: 自然免疫系タンパク質の構造 趣味: 料理 